\title{
Investigation of Rotavirus Genotypes Infection in Egypt
}

\author{
M.A.Magied ${ }^{1}$, M.Hussein ${ }^{1}$, M.Amer ${ }^{1}$, M.Sabah ${ }^{1}$, A.A.Maaty ${ }^{1}$, A.Ismaal ${ }^{1}$ andK.A.El-Dougdoug $^{2}$ \\ ${ }^{1}$ Microbiology and Botany Dept, Faculty of Science, Benha Univ., Benha, Egypt \\ ${ }^{2}$ Microbiology Dept., Faculty of Agric, Ain Shams Univ., Cairo, Egypt
}

\begin{abstract}
Rotavirus have been reported as the principal causal pathogen of acute gastroenteritis and one of the leading causes of child morbidity and mortality in Egypt .This study aimed to investigate biological, serological and molecular Rotavirus genotypes infection in Egypt. The blood and stool clinical specimens were collected randomly from 100 patients. They were analyzed for the presence of antigen and the antibody using enzyme-linked immunosorbent assay (ELISA). Rotavirus antigen in stool and antibodies in serum were detected by ELISA among Children (78.13); Female (12.5) and male (9.38\%). Rotavirus titer was determinated as $5.5 \times 10^{7} ; 6.0 \times 10^{6}$ and $7.5 \times 10^{7}$ (PFUlml) on vero cell of Female ; male and children respectively after 4 days Post infection. The cytopathic effects were granulation of cytoplasm, enlarged, swelling, rounded and multinucleated giant cells .The virus particles are non-enveloped with Icosahedral symmetry with about $70 \mathrm{~nm}$ in diameter .Rotavirus isolates showed homologous with RV isolates recorded in gene bank based on alignment and phylogenetic tree analysis. Six RV genotypes (G1P4, G1P6, G1P8, G9P6, G1P8, G3 P8) were detected in summer. Seven RV genotypes, (G1P4, G1P6, G1P8 , G3P4 , G3P6, G3P8 G9P8) were detected in in spring and five RV genotypes (G1P4, G1P8, G3P4, G3P8 G9P8) were detected in winter seasons . SDS-PAGE showed seven structural and function of proteins were polymorphism variation among for Rotavirus isolates . RV genomic migration pattern of G1P4, G1P6, G1P8 , and G9P8 were varied in number, density and segmented to 12,9, 10 , and 9 moved respectively .
\end{abstract}

Keywords: ELISA, Genotype, Rotavirus, RT-PCR , Human, Biology, Virus cultivation .

\section{Introduction}

Rotaviruses cause enteric infections that are subclinical in adult humans but that can cause death in new born humans . Rotaviruses are resistant to acidity, $\mathrm{pH}$, heat and feces are a significant cause of spreading of infection [24]. Rotaviruses are classified in the genus Rotavirus of the subfamily Sedoreovirinae in the family Reoviridae. The genome of the virus is a double-stranded RNA with 11 segments. The virus is having icosahedral symmetry, is 70 $\mathrm{nm}$ in diameter and is non- enveloped. It has a three-layered capsid consisting of an outer capsid, an inner capsid and a core. VP7 (glycoprotein) and VP4 (protease-sensitive protein) in the outer capsid stimulate the production of neutralizing antibodies. Based on the differences in the genetic regions that encode these proteins, rotaviruses are classified into the $G$ and $P$ genotypes [15]. To date, $27 \mathrm{G}$ genotypes and $37 \mathrm{P}$ genotypes have been identified in humans [1]. Infections in Egypt (Cairo, Behira, Quliobia, Giza, Alexandria, Fayoum and Sharkia). are caused by strains of rotavirus in Genotypes G1, G2 and G4 represented the highest prevalence $[40,36,3,11,26,32,42$, and 38] . Laboratory diagnosis involves the detection of Rotavirus using TEM, antigen ILFSA, ELISA and antibody ELISA techniques. Furthermore, numerous PCR methods are high sensitivity, expensive and rapid results . The RTPCR is employed using generic or type-specific primers. At present, the VP4, VP6 and VP7 regions are most often used $[1,16,18,19$ and 5] . But there was no further extensive investigation in Egypt to determine the genetic type of Rotavirus . The aim of this study was to identify the it obtained the first data on this infection in human in the area under study, and it is the Investigation of Rotavirus genotypes infection in Egypt using biological, serological and molecular assays.

\section{Materials and method \\ Collection and preparation of spesmans Safety precautions}

The study was done during winter, summer, out mum and spring at April 2018 to June 2019 . Seventy stool and thirty blood specimens were collected from patients responsible for acute enteric infection from hospitals and Special Clinical) from Qalubia and Cairo governorates, Egypt . The collected samples were taken from children , adult Male and Female .

\subsection{Preparation of clinical stool}

Approximately, $0.5 \mathrm{~g}$ of stool was resuspended in $5 \mathrm{ml}$ of $10 \%(\mathrm{w} / \mathrm{v})$ phosphate-buffered saline (PBS) $(0.01 \mathrm{M}$ Tris solution ( $\mathrm{pH} 7.5), 14.5 \mathrm{mM}, \mathrm{NaCl}$ and $10 \mathrm{mM}, \mathrm{CaCl} 2)$. Stool solution was vortexed and clarified by centrifugation at $3000 \mathrm{rpm}$ for $10 \mathrm{~min}$. The clarified supernatant (1.5-2.0 $\mathrm{ml})$ was collected and store at $4-8^{0} \mathrm{C}$ for short term storage until use.

\subsection{Preparation of clinical Serum}

Blood samples were taken from the jugular veins of the patients. Blood tubes (without EDTA) were centrifuged at $3,000 \times \mathrm{g}$ for $10 \mathrm{~min}$, and the serum samples were transferred to sterile tubes and stored in " $20{ }^{\circ} \mathrm{C}$ until analyzed .

\subsection{Transmission Electron Microscopy(TEM)}

A few drops of concentrated stool were placed on carbon-coated grids for one min, and stained with $2 \%$ PTA [2] for one min. to dry. The stained grids were examined by TEM (JEOL JEM.1400 electron microscope) in the 
Regional Center of Mycology and Biotechnology El-Azhar Univ. Cairo, Egypt (RCMB).

\subsection{Enzyme-LinkedImmunosorbent Assay (sandwich ELISA)}

Using kits (RIDASCREEN $^{\circledR}$ viral antigen and antibodies R-Biopharm AG, Germany), used for the detection RV according to the manufacturer's instructions [9]. At the end of the test, optical densities were measured with an ELISA reader (Autobio, Zhengzhou, China) at 450 $\mathrm{nm}$ absorbance according to the instructions in the test procedure.

\section{Virus cultivation}

Established Vero cell line (derived from the kidney of normal African green monkey) were obtained from American Type Culture Collection (ATCC) continuous cell line established by [53].The monolayer's of Vero cells plated was inoculated in triplicates with $100 \mu \mathrm{l}$ of serial 10 -fold dilutions $\left(10^{1}\right.$ to $\left.10^{7}\right)$ clarify the rotavirus-positive and stool specimens. The plates were incubated for $24 \mathrm{~h}$ at $37^{\circ} \mathrm{C}$ in a humidified incubator with 5\% $\mathrm{CO} 2$. Controls consisted of Uninfected monolayer in media as negative control Vero cells continue passaging to achieve high viral titers (cell lysis is evident) .

\section{Cytopathic effects}

After $48 \mathrm{~h}$ the cells were observed under inverted microscope before completing the assay to observe the difference in morphology between cell controls and infected one .

\section{Titration of Virus}

The monolayer cell was examined daily, starting from second day of incubation. Once the plaques have developed, usually by the fourth day post inoculation, count the number of plaques at each dilution, remove the agarose overlay and the plate was stained with $0.1 \%$ crystal violet solution and count the plaques again. The virus titer was estimated as a plaque forming units per $\mathrm{ml}$ (pfu $/ \mathrm{ml}$ ) as follows by counting the number of plaques at an appropriate dilution.

\section{Viral RNA Extraction}

Viral RNA was extracted from monolayer's of Vero cells plated showed cytopathic effect, cell lysis and cell death were collected at several days (up to 1 week) related to growing RV using Biozol reagent (BIOFLUX-Japan) according to the manufacturer's instructions.

\section{CDNA synthesis}

Five $\mu 1$ of extracted Viral RNA was shocked at $99^{\circ} \mathrm{C}$ for 5 min. $15 \mu 1$ mixture containing the following constituents was added to the denatured sample ; $2 \mu 1$ of $5 \mathrm{X}$ RT buffer (250 mMTris-HCl-pH 8.3), $375 \mathrm{mMKCl}, 40 \mathrm{mM} \mathrm{MgCl} 2$ ) $0.08 \mu 1$ of dNTPs and $0.25 \mu 1$ of primer (VP7FATGTATGGTATTGAA TATACCAC), Reverse transcriptase from Moloney Murine Leukemia Virus, , Taq DNA polymerase and $2.5 \mathrm{mM}$ dNTP) were obtained from Promega, USA and Bioline, Germany.

\section{Amplification of VP6 CDNA}

The c DNA was amplified by PCR technique . $1 \mathrm{ul}$ cDNA was mixed with 25ul PCR mixture ( RT buffer , $375 \mathrm{mM} \mathrm{KCl}, 40 \mathrm{mM} \mathrm{MgCl} 2$, Taq DNA polymerase and dNTP Mixture ) and primer sets , VP6-F 5'AGCACAACCTTTTCAGCACC-3'andVP6-R5'-

GTGAAAACGCGTTGCAAGTT -3' ) directly [25]

The size of PCR product was estimated by agarose gel electrophoresis comparing with standard DNA leader. The amplified fragment of with expected size $\approx 300 \mathrm{bp}$ for two samples.

\section{Analysis of amplimer sequensing}

The RT-PCR products of 4 rotavirus isolates covering all seasons were sequenced. Fifty to one hundred ul of the PCR products were purified using a high pure PCR products purification kit (Qiagen). Sequencing was performed with an ABI prism big dye termination cycle sequencing ready reaction kit (applied biosystem) using the same primers . The DNA was sequenced with an ABI prism 310 automated DNA sequenser sequence data from both strands of the PCR products and aligned by using the clustalw and blast programs (European bioinformatics institute).

\section{Detection of RV genotyping using multiplex RT-PCR}

The second round of RT-PCR amplification of cDNA was performed with specific primer sets as in Table (1) according to [20 and 21]. $P$ and $G$ genotypes were determined according to amplicon size. The amplicon sizes were estimated using a DNA ladder.

The parameters for the PCR reaction were optimized for $25 \mu 1$ and the final concentrations of reaction components were : $5 \mu 1$ of 10x PCR buffer, $4 \mathrm{mM} \mathrm{MgCl}_{2}, 4 \mu 1$ of dNTPs , $0.25 \mu l$ of each primers and $3 \mu \mathrm{l}$ of ds RNA for $4 \mathrm{RV}$ isolates $(520 \mu \mathrm{g} / \mathrm{ml})$, were used as target templates. PCR cycle parameters were as follows: one cycle at $94^{\circ} \mathrm{C}$ for 2 min ; Amplification was carried out in 35 cycles, under the following thermal cycling conditions: $94^{\circ} \mathrm{C}$ for $1 \mathrm{~min}, 48^{\circ} \mathrm{C}$ for $1 \mathrm{~min}, 72^{\circ} \mathrm{C}$ for $15 \mathrm{~s}$ and a final extension at $72^{\circ} \mathrm{C}$ for 10 min. The primers were used for amplification of a fragment which has a product size a $155 \mathrm{bp}$ amplicon according to (51) All PCR reactions were performed in a programmable thermal controller (model PTC-200, MJ Research Inc., Watertown, MA, USA). 
Table (1) Primer sequences pairs designed for genotyping of differentiate among isolates of Rotavirus (RV) specific Polymerase Chain Reaction (PCR).

\begin{tabular}{|c|c|c|c|c|c|}
\hline Primer & Sequence $5^{\prime}-3^{\prime}$ & $\begin{array}{c}\text { Target } \\
\text { gene }\end{array}$ & Primer set & $\begin{array}{c}\text { Amplicon } \\
\text { Length }\end{array}$ & Genotype \\
\hline VP7-F & ATGTATGGTATTGAATATACCAC & $\begin{array}{c}9 \\
\text { (VP7) }\end{array}$ & & & \\
\hline VP7-R & AACTTGCCACCATTTTTTCC & $\begin{array}{c}9 \\
\text { (VP7) }\end{array}$ & $\begin{array}{c}\text { VP7- } \\
\text { F/VP7-R }\end{array}$ & 881 & \\
\hline aBT1 & CAAGTACTCAAATCAATGATGG & $\begin{array}{c}9 \\
\text { (VP7) }\end{array}$ & $\begin{array}{c}\text { aBT1/VP7- } \\
\text { R }\end{array}$ & 618 & G1 \\
\hline aCT2 & CAATGATATTAACACATTTTCTGTG & $\begin{array}{c}9 \\
\text { (VP7) }\end{array}$ & $\begin{array}{c}\mathrm{aCT} 2 / \mathrm{VP} 7- \\
\mathrm{R}\end{array}$ & 521 & $\mathrm{G} 2$ \\
\hline G3 & ACGAACTCAACACGAGAGG & $\begin{array}{c}9 \\
\text { (VP7) }\end{array}$ & G3/VP7-R & 682 & G3 \\
\hline aDT4 & CGTTTCTGGTGAGGAGTTG & $\begin{array}{c}9 \\
\text { (VP7) }\end{array}$ & $\begin{array}{c}\text { aDT4/VP7- } \\
\text { R }\end{array}$ & 452 & G4 \\
\hline G8 & TTRTCGCACCATTTGTGAAAT & $\begin{array}{c}9 \\
\text { (VP7) }\end{array}$ & G8V/P7-R & 756 & G8 \\
\hline G9 & CTTGATGTGACTAYAAATAC & $\begin{array}{c}9 \\
\text { (VP7) }\end{array}$ & G9/ VP7-R & 179 & G9 \\
\hline G10 & ATGTCAGACTACARATACTGG & $\begin{array}{c}9 \\
\text { (VP7) }\end{array}$ & G10/VP7-R & 266 & G10 \\
\hline VP4-F & TATGCTCCAGTNAATTGG & $\begin{array}{c}4 \\
(\mathrm{VP} 4)\end{array}$ & & & \\
\hline VP4-R & ATTGCATTTCTTTCCATAATG & $\begin{array}{c}4 \\
\text { (VP4) }\end{array}$ & $\begin{array}{l}\text { VP4-F/ } \\
\text { VP4 R }\end{array}$ & 663 & \\
\hline 2T-1 & CTATTGTTAGAGGTTAGAGTC & $\begin{array}{c}4 \\
\text { (VP4) }\end{array}$ & VP4-F/2T-1 & 483 & P4 \\
\hline 3T-1 & TGTTGATTAGTTGGATTCAA & $\begin{array}{c}4 \\
\text { (VP4) }\end{array}$ & VP4-F/3T-1 & 267 & P6 \\
\hline 1T-1D & TCTACTGGRTTRACNTGC & $\begin{array}{c}4 \\
\text { (VP4) }\end{array}$ & $\begin{array}{l}\text { VP4- } \\
\text { F/1T1D }\end{array}$ & 345 & P8 \\
\hline $4 T-1$ & TGAGACATG CAATTGGAC & $\begin{array}{c}4 \\
\text { (VP4) }\end{array}$ & VP4-F/4T-1 & 391 & P9 \\
\hline 5T-1 & ATCATAGTTAGTAGTCGG & $\begin{array}{c}4 \\
\text { (VP4) }\end{array}$ & VP4-F/5T-1 & 583 & P10 \\
\hline $\mathbf{P}(\mathbf{1 1})$ & GTAAACATCCAGAATGTG & $\begin{array}{c}4 \\
\text { (VP4) }\end{array}$ & $\begin{array}{c}\text { VP4- } \\
\text { F/P(11) }\end{array}$ & 312 & P11 \\
\hline
\end{tabular}

Sodium dedocyl sulfate- poly acrylamide gel electrophoresis (SDS-PAGE)

Coat protein of $4 \mathrm{RV}$ isolates were analyzed banding profile qualitively and quantitatively using SDS- SDSPAGE in $12 \%$ acrylamide slab gels based on the method of (Laemmli, 1970), as modified by [44] .

\section{Extraction of viral protein}

Concentrated 4 partial purified of RV isolates , $450 \mu \mathrm{l}$ into an eppendorf tube and added $50 \mu \mathrm{l}$ of a pre-warmed solution of $1 \mathrm{M} \mathrm{Na}$ Acetate with 1\% SDS followed by vortexing for $10 \mathrm{sec}$, and incubated at $37^{\circ} \mathrm{C}$ for $15 \mathrm{~min}$. Equal volume of phenol-chloroform was added to eppendorf tube then vortexed for $1 \mathrm{~min}$, and incubate for an additional $15 \mathrm{~min}$ at $56^{\circ} \mathrm{C}$. The eppendorf tubes were vortexed for 1 min and then centrifuge at $12,000 \mathrm{rpm}$ for $3 \mathrm{~min}$. The pellets were resuspended in PBS and transferred to a fresh eppendorf tube .

\section{Electrophoresis of viral protein}

A volume of $80 \mu \mathrm{l}$ of the protein extract was loaded on $12 \%$ gels. Control wells were loaded with standard protein marker range from $14.20 \mathrm{KDa}$ to $66.00 \mathrm{KDa}$ (Fermentas.Com). The voltage was increased to 200 volt until the bromophenol blue dye reached the bottom of the separating gel. The gels were stained with the staining solution(Commassie Birlliant blue R-250 ,1gm ;Methanol,455 ml ;Glacial acetic acid ,90 ml and Distilled water $455 \mathrm{ml}$ ). The stained gels were distained with 
distaining solution (Methanol,455 $\mathrm{ml}$;Glacial acetic acid ,90 $\mathrm{ml}$ and Distilled water455 $\mathrm{ml})$.

\section{Gel Analysis}

Gels were photographed scanned, analyzed using Gel Doc VILBER LOURMAT system.

\section{Extraction of viral RNA}

\section{Results}

Detected Rotavirus (RV)
RNA bands.

Gel Analysis

ıned, analyzed using Gel Doc VILBER LOURMAT system.

and $700 \mu \mathrm{l}$ of ice-cold absolute ethanol. The eppendorf tube were mixedRgentlyntbgeinsvexsicen defecimesimanstool and serum with

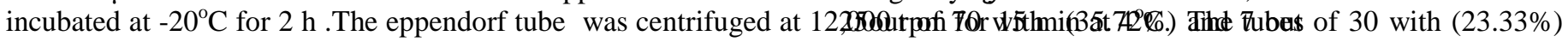

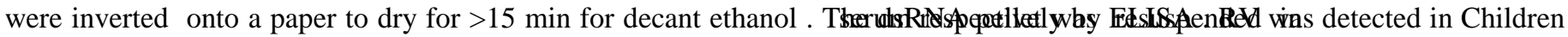
$30 \mu \mathrm{l}$ of loading buffer using the pipette .

\section{Electrophoresis of viral RNA} with $(78.13 \%)$; Female (12.5\%) and Male (9.38\%).Positive reaction was defined if the optical density (OD) of test sample exceed that of Cut off value $; \geq 0.24$.

the glass plates 7\% acrylamide was inserted in the electrophoresis apparatus. Add The running buffer was added to the bottom reservoir, in tank. The dsRNA sampleBirougioadnf rbatadidusesthe wells and electrophoresed at $150 \mathrm{~V}$ for $\sim 2 \mathrm{~h}$.

\section{Silver staining of dsRNA}

Cultivated four children' stool collected in winter, spring, summer and outmum seasons onVero cell revealed different in shape, size and number plaques form . RV titer

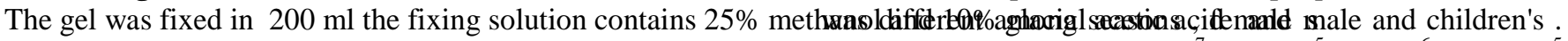

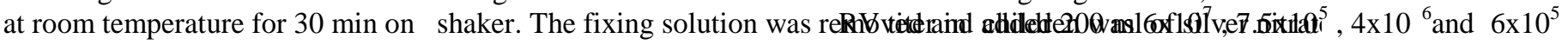
staining solution then shacked for $30 \mathrm{~min}$ at room temperature in the dRFLamshakewimitex, sispeimgitratemstainiagd outmum seasons solution, was removed then the gel was added approximately $50 \mathrm{ml}$ ofedpeetionilyg onlukiemo (colltailafteNAOAfys Post infection in formaldehyde and water and agitated by hand for $5 \mathrm{~min}$ at room templexblu(e)tardifögelany black precipitate

Table (2) Titration of Rotavirus as plaque forming units (PFU $\backslash \mathrm{ml}$ ) on of Vero monolayer cell line.

\begin{tabular}{lcccc}
\hline Patients & \multicolumn{4}{c}{ Collected seasons } \\
\cline { 2 - 5 } & Winter & Spring & Summer & outmum \\
\hline Female & $5.5 \times 10^{5}$ & $2.5 \times 10^{4}$ & $5.5 \times 10^{4}$ & $2.5 \times 10^{3}$ \\
Male & $6.0 \times 10^{6}$ & $5.0 \times 10^{4}$ & $2.0 \times 10^{5}$ & $4.2 \times 10^{4}$ \\
Children's & $6.0 \times 10^{7}$ & $7.5 \times 10^{5}$ & $4.0 \times 10^{6}$ & $6.0 \times 10^{5}$ \\
\hline
\end{tabular}

\section{Cytopathic effect of RV isolates}

The cytopathic effects begins with granulation of cytoplasm, the cells appear enlarged and swelling. Themacrocyte of infected cells become rounded take on are fractal appearance and undergo lytic degeneration. The second type of $\mathrm{CPE}$ with 5 days information of multinucleated giant cell Fig (2). The staining survival cells 125 and died cells 75 out of staining cell $=2 \times 10^{2} \mu 1^{-1}$ Cell suspension.

\section{Molecular detection of rotavirus}

Extracted RNA from Vero Cells infected with six isolate, 1 (children stool) ; isolate 2 ( children plasma), isolate 3 (female stool), isolate 4(female plasma) isolate 5 (male stool) and isolate 6 (male plasma) collected at rour seasons . The quality of purified RNA were confirmed by UV spectrophotometer were $1.5,1.4,1.6,11.4,0.7$ and 0.6 at 260/280 ratio O.D .The RNA concentration was 75 , $54,64,53,15$, and 24 ug respectively .
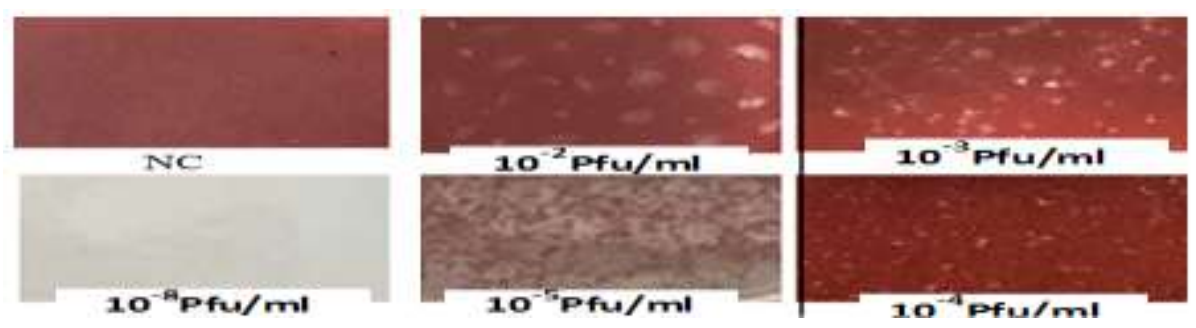

Fig (1) Vero cell line inoculated with RV showing different morphology of plaques by invert microscope. 

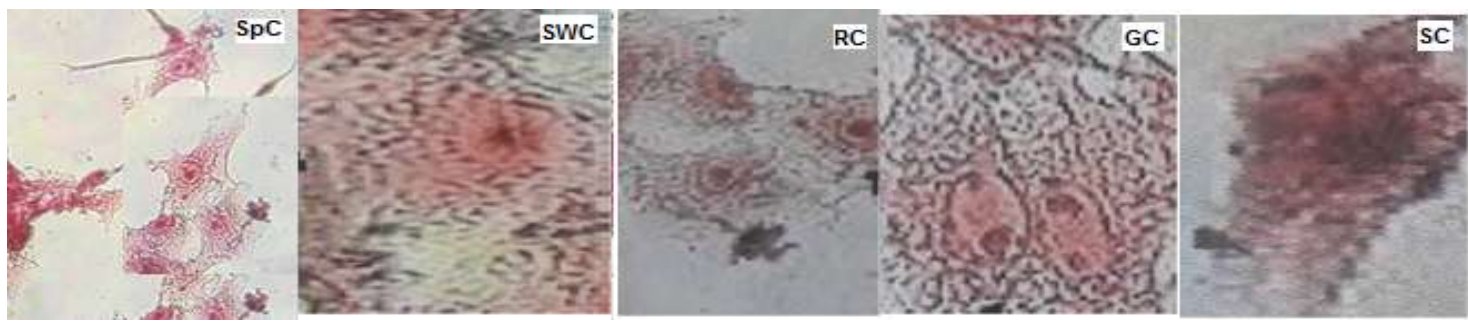

Fig (2) Cytopathic effects of Rotavirus on vero cell line showing Spindle cell (SpC), Swelling cell(Swc), Round cell (RC), Spinal cell (SC) and Giant cell (Gc) survival cells.

\section{RV morphology} Fig (3).

The virus particles are non-enveloped with Icosahedra symmetry with about $30 \mathrm{~nm}$ in diameter at $80000 \mathrm{~nm}$ magnification

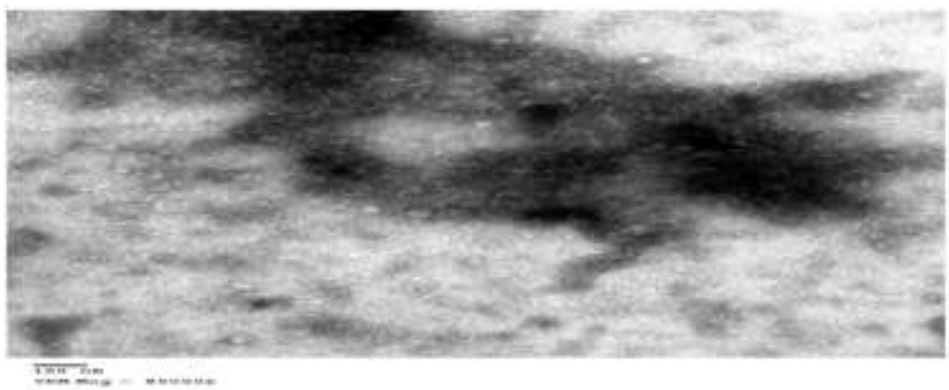

Fig (3) Electomicrographe showing the $R V$ particles appear as an Icosahedra with about $30 \mathrm{~nm}$ in diameter using negative stain method by TEM .

\section{cDNA of RV RNA}

The obtained purified RNA from samples was transcribed to cDNA using RT and complementary primer set (reverse primer, VP6-R 5'GTGAAAACGCGTTGCAAGTT-3').

\section{Amplification of RV c DNA}

The c DNA - RNA Rotavirus, isolate-1 (children stool) ; isolate 2 ( children plasma), isolate 3 (female stool), and isolate 5 (male stool) was amplified by PCR using RTPCR reaction mixture and specific primer sets, while isolate 4 (female plasma) and isolate 6 (male plasma) non amplified by PCR ones. The efficiency of VP6 gene amplification using specific primer sets by analysis P CR product using $1.5 \%$ agarose gel electrophoresis. The amplified DNA was in the expected size calculated $\approx .300 \mathrm{bp}$. Fig (4) .

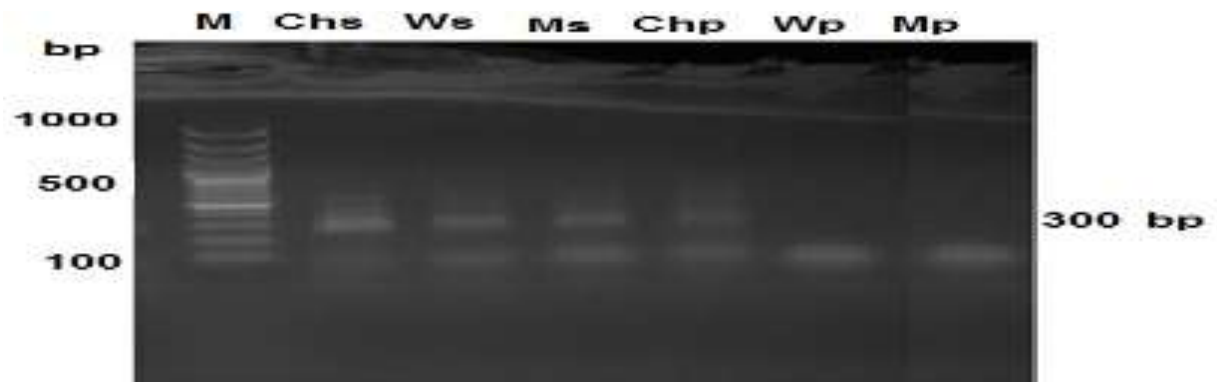

Fig (4) Electropherogram (1.5\%) showing PCR amplified product from RV RNA using specific primer sets and compared DNA leader Lane (M). children stool (Chs) ; children plssma (Chp), woman stool (Ws), woman plasma (Wp), Man stool (Ms), Man plasma (Mp) and The arrow to expected size amplified fragment $300 \mathrm{bp}$. 


\section{Phylogenetic tree}

Based on Multiple sequence alignment (MSA) analysis, the phylogenetic tree was performed and showed 13 clusters

in which the Egypt. Rotavirus.showed homologous with RV isolates recorded in gene bank Fig (5).

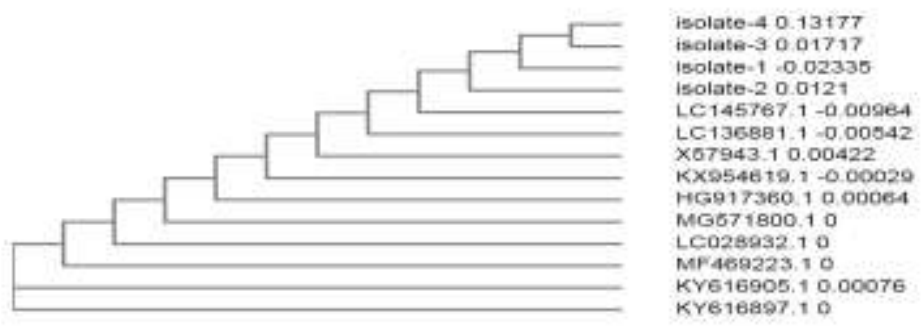

Fig (5) Phylogenetic tree representing the relationship for Rotavirus isolates between Egyptian isolates isolate,1(children stool ,Chs) ; isolate 2( children plasma , Ch p), isolate 3(woman stool,Ws) and isolate 4 (Man plasma ,Ms) based on Multiple sequence alignment of PCR amplified product from RV RNA using specific primer of vp6 genes with expected size amplified

fragment $300 \mathrm{bp}$.

\section{Genotype of rotaviruses}

The Rotavirus genotypes were detected by Multiplex RT-PCR . The data shown in Table (3) and Fig (6), showed the high rate infection (G1P4, G1P6, G1P8 , G9P6 , G1P8, G31P8) genotypes in summer. Mediate rate infection (G1P4, G1P6, G1P8 , G3P4 , G3P6, G31P8 and G9P8) genotypes in spring and low rate infection (G1P4, G1P8 , G3P4, G3P8 G9P8) genotypes in outmum . On the other hand G1P8, G31P8 genotypes in winter season Table(3).

\section{Protein content and pattern of Rotaviruses}

The RV protein of children stool ; children plasma , female stool and male stool isolates was red at $595 \mathrm{~nm}$ using the spectrophotometer and the amount of protein were calculated from the bovine serum albumin standard curve . The amount of protein were $0.69,0.60,0.54$ and $0.62 \mathrm{mg} / \mathrm{ml}$ respectively.

SDS-PAGE. showed that seven number of structure and function proteins and differed in molecular weight of Rotaviruses isolates with polymorphism variation whereas $7.1 \%$ Monomorphic (common bands) , $14.4 \%$ Polymorphic(specific bands) and 29\% Unique( Genetic marker ). As well as showed RV children stool has 4 Unique (Genetic marker) with molecular weight about111,30,20 and $10 \mathrm{KDa}$. , RV children plasma has 3 Unique ( Genetic marker) with molecular weight about 45, 37 and 27 molecular weight .RV woman stool in Table (4) and fig (7) . it can concluded RV children stool (ChS) ; children plasma (ChP), woman stool (WS) and Man stool (MS)are differed in their protein content qualitatively related to protein marker (M) Table (4) .

Table (4) Protein pattern and polymorphism among Rotaviruses isolated from stooland plasma of children, woman and man patiants .

\section{Nucleic acid content of Rotavirus particles}

The amount of RV Nucleic acid isolated from children stool (ChS); children plasma (ChP), woman stool (WS) and Man stool (MS) was determined by UV Spectrophotometer at $260 \mathrm{~nm}$ length . The amount were 0.28 $, 0.38,0.45$ and $.0 .35 \mu \mathrm{g} / \mathrm{ml}$ respectively.

\section{Genome pattern of Rotavirus}

The $R V$ genome were determined by $6 \%$ polyacrylamide gel electrophoresis using selver stain. The genomic segments migration pattern of G1P4, G1P6, G1P8 , and G9P8) was observed, where segments $12,9,10$, and 9 moved in a plet. Lane (G1P4 , G1P6 , G1p8 and G9P8 respectively ) showing long electropherotypes based on relative migration dye stain .. The obtained results showed that variation in number and density of genomic patters of Rotaviruses isolated from stool and plasma of children, woman and man patients Fig (8) .

Table (3) Seasonal distributions of Rotavirus genotypes in stool and serum of patients

\begin{tabular}{ccccccc}
\hline Season & Samples & G-type & \multicolumn{3}{c}{ P-Type } & Total \\
& & & P4 & P6 & P8 & \\
\hline Winter & Stool & G1 & 1 & ND & 3 & 4 \\
& & G3 & 1 & ND & 2 & 3 \\
& \multirow{2}{*}{ Serum } & G1 & ND & ND & 1 & 1 \\
& & G9 & ND & ND & 1 & 1 \\
\hline
\end{tabular}




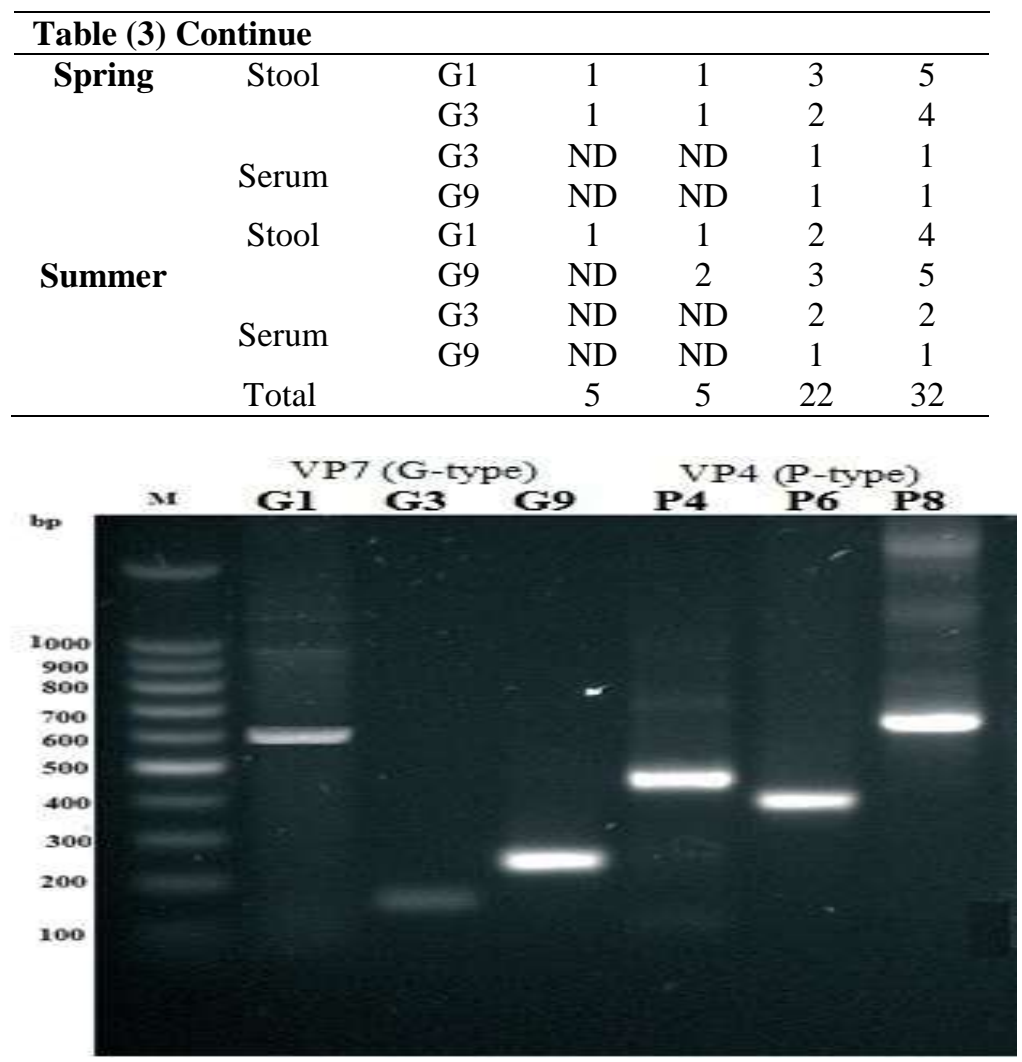

Fig (6) Gel electrophoresis positive stool sample for G9-rotavirus genotype in spring season (male less than 12 months), which have a molecular size $179 \mathrm{bp}$.

Table (4)

\begin{tabular}{|c|c|c|c|c|c|}
\hline \multirow[t]{2}{*}{3} & \multicolumn{4}{|c|}{ Rotaviruses isolates } & \multirow[t]{2}{*}{ polymorphism } \\
\hline & ChS & ChP & WS & MS & \\
\hline 120 & +++ & - & +++ & ++ & Polymorphic \\
\hline 111 & +++ & & - & - & Unique \\
\hline 70 & & ++ & ++ & + & Polymorphic \\
\hline 55 & ++++ & ++ & ++ & + & Monomorphic \\
\hline 45 & - & ++ & - & - & Unique \\
\hline 37 & - & +++ & - & - & Unique \\
\hline 35 & - & ++ & ++ & ++ & Polymorphic \\
\hline 30 & ++++ & & - & & Unique \\
\hline 27 & - & + & - & - & Unique \\
\hline 25 & ++++ & + & ++ & ++ & Monomorphic \\
\hline 20 & ++++ & - & - & - & Unique \\
\hline 10 & ++++ & - & - & - & Unique \\
\hline 8 & - & - & +++ & +++ & Polymorphic \\
\hline Total & 7 & 7 & 7 & 7 & \\
\hline
\end{tabular}

Monomorphic $=$ common bands $7.1 \%$

Polymorphic $=$ specific bands $14.4 \%$

Unique $=$ Genetic marker $29 \%$

$(+++)$ high density
(-) No detect band

$(+)$ Low density band $(++)$ moderate density (++++) Strong density 


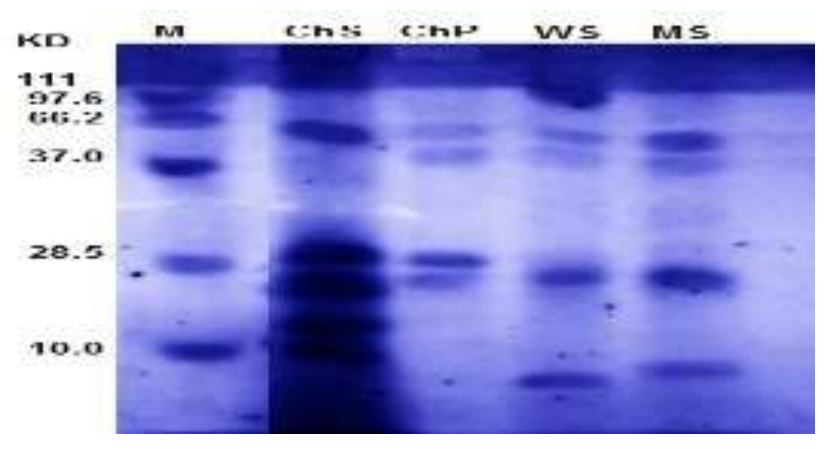

Fig (7) SDS-PAGE 12\%Photogram showing protein content of purified RV isolated from children stool $(\mathrm{ChS})$; children plasma (ChP), woman stool (WS) and Man stool (MS) related to protein marker $(\mathrm{M})$.

\section{Discussion}

Rotaviruses causes severe childhood diarrhea, belong to the family Reoviridae, non-enveloped and segmented ds RNA . The development of rapid and sensitive diagnostic assays is importance for diagnosing and monitoring consequently reduces hospital stays. The efficiency of diagnosis also allows for proper precautions to be taken to prevent for minimize RV spread .

In the present study, Rotavirus was serological detected in $35.72 \%$ of stool samples by antigens and in $23.33 \%$ serum samples by antibodies using ELISA collected from different hospitals belong Qalubia and Cairo governorates. It was spread between Children cases $78.13 \%$; female cases $12.5 \%$ and male cases with $9.38 \%$.Clinical stool 45out of 70 collected samples were negative results Rotavirus and the infection may be related to parasites. These results are similar to the previous reports by [13 and 38] and these findings regarding the seasonal distribution are partially in agreement with the previous report which suggested no seasonal variations for adenovirus [29]. Serological investigations can only help in the diagnostic confirmation of a rotavirus enteritis, since $\operatorname{IgM}$ antibodies can only be detected from the fifth day after the onset of the disease. An earlier diagnosis is therefore not possible [29] . ELISA technique has been adapted by the world Health Organization as the standard method for the detection of RV antigen in samples. ELISA have the advantage of given numerical result which can be objectively interpreted but they require multiple steps in processing and usually are not cost effective for testing small number of specimens [8 and 46].

Cultivation of concentrated gave a The clinical stool positive ELISA result of RV antigen cultivated on Vero cell were revealed different in size and number plaques after 4 days Post infection. The cytopathic effects could be attributed to apoptosis induced by the virus [44]. Our result agree with the study results of [27, 37 and 10]. Rotavirus

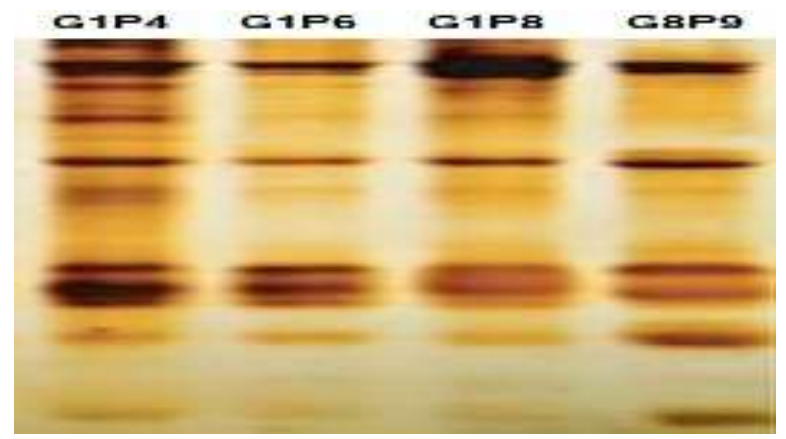

Fig (8) RNA-polyacrylamide gel electrophoresis of children stool (ChS) ; children plasma (ChP), woman stool (WS) and Man stool (MS) samples for detection of Rotavirus. The genomic segments migration pattern 1 of G1P4, G1P6, G1P8 , and G9P8) was observed, where segments .

infection in vitro was associated to several sub-cellular pathological changes that ultimately culminate with cell lysis. The rotavirus and host interaction due to changes may represent a key role in the pathogenesis of diarrheic disease and death of cells has been established as being caused by lytic process [15].

The isolated RV are non-enveloped, Icosahedral symmetry with about $30 \mathrm{~nm}$ in diameter in concentrated stool investigated with negative stain method by TEM at $80000 \mathrm{~nm}$ magnification. TEM viral morphology includes virus-like-particles, i.e. electron-dense particles with ahexagonal to round shape and a diameter of RV is $30 \mathrm{~nm}$ [29].EM is of low sensitive as the specimens should contain approximately $10^{6}$ viral particle $/ \mathrm{ml}$ to be detected [30 and 35].

RNA was extracted from Vero Cell line infected with RV isolates (Chs, Chp, Fs and Ms). The quality of purified RNA were confirmed by UV spectrophotometerat 260/280 ratio O.D and different concentration for Chs , Chp , Fs , Ms .The obtained purified RNA from samples was transcribed to cDNA using RT and complementary primer set (reverse primer, VP6-R 5'GTGAAAACGCGTTGCAAGTT-3').

The c DNA - RNA Rotavirus was amplified by PCR technique using RT-PCR reaction mixture and specific primer sets. The efficiency of VP6 gene amplification using specific primer sets by analysis PCR product using $1.5 \%$ agarose gel electrophoresis. The amplified DNA was in the expected size calculated $\approx .300 \mathrm{bp}$. RT-PCR analysis (using the highly conserved the sixth viral structural proteins, VP6) of Rotaviruses of water samples and vegetable sample [11, 13 and 14]. The French report emphasized that the winter epidemics of Rotavirus infections was associated with a high level of inter human transmission, after analyzed drinking waters of children suffering from Rotaviral gastroenteritis by RT-PCR [39]. 
PCR assays can be developed based on genotypic differences between viruses with different host groups and can be used to better characterize sources of contamination in aquatic environment so that an appropriate and cost effective water quality remediation plan can be developed. [17]. In the case of environmental samples, amplification of viral nucleic acids by polymerase chain reaction (PCR) assays coupled to reverse transcription (RT-PCR) has been water and shellfish.[48]. Based on Multiple sequence alignment (MSA) analysis, the phylogenetic tree was performed and showed 13 clusters in which the Egypt. Rotavirus. showed homologous with RV isolates recorded in gene bank

The genotypes $\mathrm{G}$ and $\mathrm{P}$ of $\mathrm{RV}$ four isolates ; ChS;ChP;WS and MS were detected by Multiplex RT-PCR correspond to VP7 (glycoprotein) and VP4 (protease protein). The obtained data showed the high rate infection in summer. Mediate rate infection in spring and low rate infection in winter and outmum seasons . To date, twentyseven and thirty-seven of G- and P- genotypes for human rotaviruses were identified [47]. The most common human RVA genotypes circulating in the worldwide are G1P[8], G2P [4], G3P[8], G4P[8] and G9P[8], [41]. Many previous reports targeted Rotavirus genotyping among children had been conducted in different districts in Egypt (Cairo, Behira, Quliobia, Giza, Alexandria, Fayoum and Sharkia). Genotypes G1, G2 and G4 represented the highest prevalence [3, 26 and 32].

However, in a nearby governorate (Sharkia), [22] recorded higher prevalence of G1, G9 and G3 (55\%, 14.5\% and $22.2 \%$ Strain combinations G1P[8], G2P[4], G3P[8], G4P [8] and G9P[8] have been shown to contribute to over $90 \%$ of rotavirus infections worldwide. Of these, the G1P[8] genotype is predominant in most region [41]. Further, all the PAGE positive samples were genotyped ( $G$ and $P$ ) using the multiplex PCR assay [52].

The viral protein was read at $595 \mathrm{~nm}$ using the spectrophotometer and the amount of protein were calculated from the bovine serum albumin standard curve .

The structural and function proteins for Rotaviruses were determined using $12 \%$ SDS-polyacrylamide gel electrophoresis. The obtained results showed that seven number of protein patters were differed in molecular weight of among RV isolates with polymorphism variation and Unique ( Genetic marker) .The capsid proteins are responsible for many of the serologic properties of Group A rotaviruses. Host antibodies to the VP6 protein define the rotavirus group antigen. Results from studies of animal models suggest that antibodies to VP6 and a viral nonstructural protein, NSP4, might also be involved in generation of protective immunity [6]

The obtained results showed that variation in number and density of genomic patters. Genome patterns of RV isolates were determined by $6 \%$ PAGE using salver stain . The segmented genomic of 4 isolates were $12,9,10$ and 9 segments moved in a plot. respectively. In RNA-PAGE all the RV exhibited migration pattern of its genomic segments, where segments 7, 8, 9 moved in a triplet, typical of group A rotaviruses [43]. Moreover, a genotype classification system using the sequence of all 11 genomic RNA segments has been suggested for differentiating genotypes [34,a and b ] .

\section{References}

[1] F.Alkan, V.Gulyaz, M.O.Timurkan, S.Iyisan, S. Ozdemir, and N. Turan, A large outbreak of enteritis in goat flocks in Marmara, Turkey, by G8P[1] group A rotaviruses. Arch. Virol., Vol.157, PP.1183-1187,2012.

[2] J.D.Almeida and A.P. Waterson, Viruses. In Electron Microscopy in Human Medicine. Infectious agents.(Mac Graw-Hill, UK), p.3, 1980.

[3] M.A.Amer, S.M. Abdel H.A. Salam, M. Ibrahim, Farag , Detection of group A Rota virus and characterization of G type among Egyptian children with diarrhea. Egyptian J. Med. Microbiol, Vol. 16(1), PP.123-132, 2007.

[4]A.Badaracco,L.Garaicoechea,J.Matthijnssens, A.Louge Uriarte Odeon, G.Bilbao, F.Fernandez, G.I.Parra, and V.Parreno, Phylogenetic analyses of typical bovine rotavirus genotypes G6, G10, P[5] and P[11] circulating in Argentinean beef and dairy herds. Infect. Genet. Evol, Vol.18, PP.18-30, 2013.

[5] A.Badawi Othman1, A.Khaled El-Dougdoug1, F.Aly Mohamed2, A.Abeer Faiesal3 and A.Naglaa Saif4, Evaluation of Serological and Molecular Detection Vegetable Borne Rotavirus in EgypCurrent Science International , Vol.5 (4),| PP.606-618, 2016.

[6] J.M.,Ball , P.,Tian, C.Q.Y.,Zeng , A.P.Morris , and MK.Estes , Age-dependent diarrhea induced by a rotaviral nonstructural glycoprotein. Science, PP.272:101-4, 1996.

[7] K,Banyai B,Laszlo J,Duque et al, Systematic review of regional and temporal trends in global rotavirus strain diversity in the pre rotavirus vaccine era: insights for understanding the impact of rotavirus vaccination programs. Vaccine.;30 Suppl 1:A122130.doi:10.1016/j.vaccine.2011.09.111, 2012.

[8] G.M.Beards, A.D.Campbell, N.R.Cottrell, J.S.Peiris, N. Rees, R.C. Standers, J.A.;Shirley, H.C.Wood; and T.H.Flewett, ,Enzyme-linked immunosorbent assay based on polyclonal and monoclonal antibodies for Rotavirus detection . J. Clinical Microbiology .Vol.19, PP.248-254, 1984.

[9] B.S.Coulson, and I.H.Holmes, An Improved EnzymeLinked Immunosorbent Assay for the Detection of Rotavirus in Faeces of Neonates.Journal. Virology Methods, Vol.8, PP.165-179, 1984.

[10] K.A.El-Dougdoug, B.A.Othman, A.F .Mohamed, and A.Naglaa Seif (2018).Identification of Enterovirus contaminated Drainage water and vegetables, JVS Abstract.

[11] W.M.El-Senousy ; and E.M. El-Mahdy, Detection and genotyping of RVAes in water treatment plants of El- 
Dakahlia Governorate. Egyp. J. Biotechnol. Vol.31, PP.25-34, 2009.

[12] W.M.El-Senousy, A.B.Barakat, H.E.Ghanem, and M.A.Kamel, Molecular epidemiology of human adenoviruses and rotaviruses as candidate viral indicators in the Egyptian sewage and water samples. World Applied Sciences J. , vol.27, PP.1235-1247, (2013a).

[13] W.M.El-Senousy, A.B.Barakat, H.E.Ghanem, and M.A.Kamel, Molecular epidemiology of human adenoviruses and rotaviruses as candidate viral indicators in the Egyptian sewage and water samples. World Appl. Sci. J, Vol.27, PP.1235-1247, 2013 b.

[14] W.M.El-Senousy, M.S.El-Gamal, A.A.Mousa, S.E.ElHawary, and M.N.Fathi, Prevalence of Noroviruses among Detected Enteric Viruses in Egyptian Aquatic Environment. World Applied Sciences J., Vol.32 (11), PP.2186-2205, 2014.

[15] M.K.Estes, Rotavirusand their replication. In FieldsVirology, 4th Ed, Knipe, D.M. and Howley, P.M. (eds). Philadelphia; PA: Lippincott Williams and Wilkins, PP.1747-1785, 2001.

[16] E.Falcone, M.,Tarantino, L.,Di Trani, P.,Cordioli, A.Lavazza, and M.Tollis, Determination of bovine rotavirus $\mathrm{G}$ and $\mathrm{P}$ serotypes in Italy by PCR. J. Clin. Microbiol, Vol. 37, PP.3879-3882, 1990.

[17] T.T. Fong, and K.E.Lipp,.Enteric Viruses of Humans and Animals in Aquatic Environments: Health Risks, Detection, and Potential Water Quality Assessment Tools. Microbiology and Molecular Biology Reviews, Vol.69 (2), PP.357-371, 2005.

[18] L.,Garaicoechea, K.,Bok, L.R.,Jones, G.,Combessies, A.,Odeon, F.Fernandez, and V.Parreno, Molecular characterization of bovine rotavirus circulating in beef and dairy herds in Argentina during a 10-year period (1994-2003). Vet Microbiol, Vol.118, PP. 1-11, 2006.

[19] S., Gazal, A.K.Taku, and B.Kumar, Predominance of rotavirus genotype G6P[11] in diarrhoeic lambs. Vet. J., Vol.193, pp299-300, 2011.

[20] V,Gouvea RI,Glass P,Woods K,Taniguichi HF,Clark B,Forrester ZY.Fang Polymerase chain reaction amplification and typing of rotavirus nucleic acid from stool specimens. J Clin Microbiol , Vol.28, PP.27682,1990 .

[21] J.Gray, and M.Iturriza-Gómara, Rotaviruses. Methods in Molecular Biology, Vol.665, PP.325-355, 2011

[22] S.E.Hashem; A. Sahar, S.A. Shoman, S.A. Zaki and A.F. Elsayed, Isolation and molecular genotyping of group A RVA strains circulating among Egyptian infants and children. Austr. J. Basic APP. Sci. Vol6(6), PP. 361367, 2012.

[23] AJ,Herring NF,Inglis CK,Ojeh DR,Snodgrass JD.Menzies, Rapid diagnosis of rotavirus infection by direct detection of viral nucleic acid in silver-stained polyacrylamide gels. J Clin Microbiol , Vol.16, PP.4737, 1982.
[24] J.M. Hyser, and M.K.Estes , "Rotavirus vaccines and pathogenesis: 2008". Current Opinion in Gastroenterology. $25 \quad$ (1): 36-43. doi :10.1097/MOG.0b013e328317c897. PMC 2673536. PMID 19114772. induced by a rotaviral nonstructural glycoprotein. Science;272:101-4. Iturriza-, 2009.

[25]M.Gomara,; C.Wong, ; S.Blome,; U.Desselberger, and J.Gray, Molecular characterization of VP6 genens of human rotavirus isolats: Correlation of genogroups with subgroups and evidence of independentsegregation.Journal Virology.76.6596-6601, 2002.

[26] A.Kamel,; M.,Ali, H.,El-Nady, S.,Aho, P.Pothier, and G.Belliot, Evidence of the co-circulation of enteric viruses in sewage and in the population of Greater Cairo.Appl. Microbiol., Vol.108, PP.1620-1629, 2009.

[27] L.Kittigul, ; P.Khamoun, ; D,.Sujirarat , ; F.Utrarachkij, K.Chitpirom, N.Chaichantanakit, and K.Vathanophas, An Improved Method for Concentrating Rotavirus from Water Samples Rio de Janeiro, Vol.96, PP. 1-7, 2001.

[28] U. K.Laemmli, during the assembly of the head of bacteriophage T4.Cleavage of structural proteins Nature (London) 227, PP.680-685, 1970.

[29] H.Lin, ; C.Kao,; C.Lu,; C.Lee,; T.Chiu,; P.Lee,; H.Tseng,; H.Hsu,; C.Lee, and L.Huang, Enteric adenovirus infection in children in Taipei. J. Microbiol. Immunol. Infect. Vol.33, PP.176-180, 2000.

[30] C.R. Madeley, and B.P. Cosgrove, Letter: Viruses in infantile gastroenteritis. Lancet.2:124, 1975.

[31] YPS.Malik, K,Sharma N,Vaid S,Chakravarti K M, Chandrashekar SS, Basera Singh R, Minakshi, Prasad S, Gulati B R, Bhilegaonkar K N and Pandey A B. Frequency of group $A$ rotavirus with mixed $G$ and $P$ genotypes in bovines: predominance of G3 genotype and its emergence in combination with G8/G10 types. $J$. Veterinary Science, Vol.13(3), PP.271-278, 2012.

[32] D.O.Matson ; I.A. Abdel-Messih, C.D. Schlett, K. Bok, T. Wienkopff, T.F. Wierzba, J.W. Sanders and R.W.Jr. Frenck, RVA Genotypes among hospitalized children in Egypt, 2000-2002. J. Infect. Dis. 202(S1): S263-265, 2010.

[33] J,Matthijnssens M,Ciarlet E,Heiman et al. Full genomebased classification of rotaviruses reveals a common origin between human Wa-Like and porcine rotavirus strains and human DS-1- like and bovine rotavirus strains.JVirol.;82(7):3204-3219. doi:10.1128/jvi.0225707, (2008a).

[34] J,Matthijnssens M,Ciarlet M,Rahman et al. (2008b). Recommendations for the classification of group A rotaviruses using all 11 genomic RNA segments.ArchVirol.;153(8):1621-1629. doi:10.1007/ s00705-008-0155-1.

[35] S.Mijatovic -Rustempasic ; K.1.Tam J.M.Lewis; R Gautama, O.Quaye , J.R.Gentsch , and Bowen, M.D, Sensitive and specific quantitative detection of Rotavirus A by One-step real time reverse transcription -PCR 
assay without antecedent double strand -RNA denaturation J. Clinical Microbiology , Vol.51, PP.347354, 2013.

[36] A.B.Naficy; R. Abu-Elyazeed, J.L. Holmes, M.R. Rao, S.J. Savarino, Y. Kim, T.F. Wierzba, L. Peruski, Y.J. Lee, J.R. Gentsch and others, Epidemiology of RVA diarrhea in Egyptian children and implications for disease control. Am. J. Epidemiol. Vol.150(7), PP.770777, 1999.

[37] A .Naglaa, Seif , Isolation and identification os some food borne viruses. MS.C Fac. of Agric. , Ain Shams Univ.PP.168, 2016.

[38] M.M. Nourhan Saeed, Detection and Genotyping of Viral Diarrhea Disease among Egyptian Children. M.Sc, Faculty of Science, Helwan University , pp102, 2019.

[39] A.Y.Othman,; M.W. El-Senousy, A.A. El-Morsi, and K.M.Rashed, Efficiency of Traditional Water Treatment Plant and Compact Units in Removing Viruses. International J.Applied Sciences Biotechnology, Vol.3(3), PP.528-536, 2015.

[40] S.F.Radwan , M.K.Gabr, S.El-Maraghi , and A.F. ElSaifi , Serotyping of group A RVAes in Egyptian neonates and infants less than 1 year old with acute diarrhea. J. Clin. Microbiol. Vol.35(11), PP.2996-2998, 1997.

[41] N.Santos, and Y.Hoshino, Global distribution ofrotavirus serotypes/genotypes and its implication for the development and implementation of an effective rotavirus vaccine. Rev. Med. Virol. Vol.15, PP.29-56, 2005.

[42] N.Saudy, W.O.Elshabrawy , A.Megahed, M.F.Foad, A.Mohamed , Genotyping and Clinic epidemiological Characterization of Rotavirus Acute Gastroenteritis in Egyptian Children. Pol. J. Microbiol, Vol.65, PP. 433442, 2016.

[43] A.D.Steele, A.Geyer, G.Gerdes Rotavirus infections. In: Coetzer JT, ed. Infectious diseases of livestock, 2nd ed. Cape Town: Oxford University Press; p.1256-64, 2004.
[44] F.W. Studier, Analysis of bacteriophage T7 early RNA and protein of slab gels. Molecular Biol. 79, PP.237-248, 1973.

[45] F.Superti, M.G.Ammendolia, A.Tinari , B.Bucci , A.M.Giammarioli, G.Rainaldi, R.Rivabene, and G.Donelli , Induction of apoptosis in HT-29 cells infected with SA-11 rotavirus. J Med Virol, Vol.50, PP.325-334, 1996.

[46] E.E.Thomas, M.L.Puterman, E.Kawano , and M.Curran, Evaluation of seven immunoassay for detection of Rotavirus in pediatrict stool samples. J.Clinical Microbiology, Vol.26, PP.1189-1193, 1998.

[47] E.Trojnar, J.Sachsenroder, S.Twardziok, J.Reetz, P.H.Otto, and R.Johne, Identification of an avian group A rotavirus containing a novel VP4 gene with a close relationship to those of mammalian rotaviruses. J. Gen.Virol, Vol.94, PP.136-142, 2013.

[48] P.Vasickova, L.Dvorska, A.Lorencova, I.Pavlik (2005).Viruses as a cause of foodborne diseases.VeterinarniMedicina 50, 89-104.

[49] World Health Organization , Manual ofrotavirus detection and characterization methods . pp 149 , 2009.publication is available on the www.who.int/vaccines-documents .

[50] World Health Organization (WHO), Guidelines for drinking-water quality. Geneva, Switzerland. 3rd ed, vol .1, p.515, 2004.

[51] H.Yan, T.A.Nguyen, S.Okitsu, Y.Li, and H.Ushijima , Development of RT-multiplex PCR for detection of Adenovirus and Rotavirus in diarrheal fecal specimens from children in china. J. Clin. Microbiol. Vol.78, PP. 699-709, 2004.

[52] A.Yashpal , S. M. Kuldeep, S., Naveen, K.., Adiel, A. H.. and V.Nirupma , Determination of bovine rotavirus genotypes ( $\mathrm{G}$ and $\mathrm{P}$ ) circulating in , 2014

[53] Y.Yasumura, and Y.Kawakita, Studies on SV40 in tissue culture-preliminary step for cancer research "in vitro".Nihon Rinsho.21, PP.1201-1215, 1963. 